\title{
EFFECT OF NITROGEN SOURCE AND RATE AS WELL AS SOME MICRO ELEMENTS TREATMENTS ON YIELD AND YIELD COMPENENTS OF MAIZE UNDER SALT AFFECTED SOILS CONDITIONS
}

El-Gharieb, A. E.*; M. A. El-Hawary*; S. D. Darwish** and O. A. R. Neowito*

* Agron. Dept., Fac. Agric., Al-Azhar Univ., Cairo, Egypt.

** Soil and water institute, Agric. Res. Center, Giza, Egypt.

\begin{abstract}
Two field experiments were carried out at Demo-El-Faiyoum ,Governorate in 2002 and 2003 seasons to study the effect of two nitrogen sources (Ammonia gas and Urea), three nitrogen rates $(100,120$ and $140 \mathrm{~kg} \mathrm{~N} / \mathrm{fad}$ ) and six micro element treatments ( $\mathrm{Zn}, \mathrm{Fe}$ and $\mathrm{Zn}+\mathrm{Fe}$ as a soil and foliar application methods) on yield and yield components of maize. The experiment was laid out in split-split plot design. The obtained results showed clearly that plants received nitrogen fertilizer in the form of ammonia gas gave the highest values of ear length ,100 grain weight, grain yield per fad and protein percentage in grain as compared with those received nitrogen source of urea. Increasing nitrogen fertilizer rate from 100 to $140 \mathrm{~kg} \mathrm{~N} / \mathrm{fad}$ significantly increased ear length , 100 grain weight , stover and grain yield per fad and protein percentage in grain. Sprayed maize plants with mixed from micro elements $\mathrm{Zn}+\mathrm{Fe}$ as a foliar application surpassed all other treatments in all previously mentioned characters. Applied ammonia gas as a source of nitrogen at the rate of $140 \mathrm{~kg} \mathrm{~N} / \mathrm{fad}$ gave the highest ear length, grain yield per fad and grains protein percentage. Plants grown on soil injected by ammonia gas and sprayed with mixed from micro elements $\mathrm{Zn}+\mathrm{Fe}$ gave higher grain yield per fad and protein percentage than other treatments. Plants fertilized with $140 \mathrm{~kg} \mathrm{~N} / \mathrm{fad}$ and sprayed with micro element mixed $\mathrm{Zn}+\mathrm{Fe}$ gave the highest ear length, grain yield / fad and protein \%. Plants treated with ammonia gas at $140 \mathrm{~kg} \mathrm{~N}$ fad and sprayed with mixed from micro elements gave the highest ear length, grain yield per fad.

Generally, it could be recommended that applying nitrogen in the form of ammonia gas at the rate of $140 \mathrm{~kg} \mathrm{~N} / \mathrm{fad}$ and sprayed with mixed from $\mathrm{Fe}+\mathrm{Zn}$ micro elements gave greatest grain yield of maize grown under salt affected soils at EIFaiyoum Governorate conditions.
\end{abstract}

\section{INTRODUCTION}

Maize (Zea mays, L.) is one of the most important cereal crops in the world. In Egypt maize is a great important for human consumption (20\% mixed with Wheat flower to reduce the imported quantity of Wheat),animal and poultry feeding as well as industrial purpose. Nowadays, the first step of the Egyptian strategic aims to bridge the gap between production and consumption of maize. Such increase of productivity is likely to be obtained byincreasing cultivated new areas with maize and increasing the productivity of unit area.Most of the new areas face some stress problems, i.e salinity, drought and unbalance nutrient elements. Salinity is a major environmental problem that cause a reduction in plant productivity. Salinity stress is causing 


\section{El-Gharieb, A. E. et al.}

poor response of crops to fertilizer application.There for it is necessary to mange such soils for profitable agriculture by adopting on farm management practices. Attempts have been made to over come these injurious effect of salinity on growth and yield of maize crop, one of these attempts is likely to be applied the adequate fertilization. Nitrogen is an essential nutrient for maize production. Management system must be developed for efficient nitrogen utilization for maximizing maize production.

Source of nitrogen application is important management tool in this respect because maximum nitrogen efficiency is obtained when nitrogen is applied in the form which is available for uptake by plants as needed. Hammam (1995), reported that the highest values of ear length, 100 kernel weight and grain yield of maize were recorded with the addition of ammonium nitrate compared to urea and calcium nitrate. The superiority of $\mathrm{N}$ sources for grain yield was in the order of urea fromaldhyd $>$ ammonium sulphate $>$ ammonium nitrate ( El- Nemr et al.1996). El- Sayed et al. (1998) showed that the application of ammonium gas fertilizer gave the highest grain yield and protein content in grain of maize compared to the other nitrogen sources. Osman et al.(2001) found that the effect of different nitrogen sources was significant on 100 grain weight, grain yield (t/fed) and grain protein content of maize.

Nitrogen is a major nutrient element and it is needed in large amount for high yield of maize, it considers the most factors affecting the growth and productivity of maize plants. Darwish (2003), Mohamed(2004), Leilah et al.(2009) and Ragab and Ibrahim(2009 a and b), reported that increasing nitrogen fertilizer rate up to $120 \mathrm{~kg} \mathrm{~N} / \mathrm{fad}$ increased ear length, 100 grain weight, stover yield/fad, grain yield/fad and protein contnent in grain of maize.

Micro elements such as $\mathrm{Zn}$ and Fe have become limiting factors for increasing maize productivity. Egyption soil had the high $\mathrm{PH}$, it is considered a problem to available of micro element i.e $\mathrm{Zn}$ and Fe. Foliar application was the best method for $\mathrm{Zn}$ and $\mathrm{Fe}$ uptake. This may be due to the quick absorption of the elements by spraying, and concequcntly could solve the problem of unavailability of micronutrient. Abdel Messih et al. (1999), Omran (2000), Osman et al (2001), El-Akbawy et al(2001),

El-Nagar(2002) and Darwish (2003) reported that spraying plants with Zn and $\mathrm{Fe}$ increased ear length, 100 grain weight, stover yield/fad, grain yield/fad and protein percentage in grains.

Therefore, this investigation was laid out to study the effect of nitrogen source and rate and some micro elements treatments on yield and its component of maize in salt affected soils under EL-Faiyoum Governorate conditions.

\section{MATERIALS AND METHODS}

Two field experiments were carried out at Demo -El Faiyoum Governorate in 2002 and 2003 seasons to study the effect of nitrogen source and rate as well as some of micro elements treatments on yield and yield components of maize under salt affected soils. 


\section{Studied factors}

\section{A-Nitrogen source}

Two nitrogen sources were tested as follows:

1-Ammonia gas injection(82\%)

2-Urea fertilizer $(46 \% \mathrm{~N})$

Ammonia gas was mechanically injected in the soil after seed bed preparation and 7 days beriore sowing at the following studied nitrogen rates. While urea was placed on the soil surface before 1 st and 2nd irrigations.

\section{B- Nitrogen fertilizer rate}

Three nitrogen rates were applied as follows:

$1.100 \mathrm{~kg} \mathrm{~N} / \mathrm{fad}$.

$2.120 \mathrm{~kg} \mathrm{~N} / \mathrm{fad}$.

$3.140 \mathrm{~kg} \mathrm{~N} / \mathrm{fad}$.

Nitrogen fertilizer in the form of Urea at the previously mentioned rates were applied in two equal parts, the first was applied before the first irrigation and the second part was applied before the second irrigation in both seasons.

\section{C- Micro elements treatments:}

1- Application of chelated iron( $\mathrm{Fe})$ fertilizer at the rate of $2 \mathrm{~kg} / \mathrm{fad}$ as a soil application.

2- Application of chelated $\operatorname{zinc}(\mathrm{Zn})$ fertilizer at the rate of $2 \mathrm{~kg} / \mathrm{fad}$ as a soil application .

3- Application of mixed from iron and Zinc chelated(1:1 ratio) at the rate of 2 $\mathrm{kg} / \mathrm{fad}$ as a soil application.

4- Application of chelated $\mathrm{Fe}$ at the concentration of $0.6 \mathrm{~g} /$ liter as a foliar application.

5- Application of chelated $\mathrm{Zn}$ at the concentration of $0.6 \mathrm{~g} / \mathrm{liter}$ as a foliar application.

6- Application of mixed from $\mathrm{Fe}$ and $\mathrm{Zn}(1: 1$ ratio) at the concentration of 0.6 $\mathrm{g} /$ liter as a foliar application.

Micro elements were applied as the soil application method before sowing with the previously mentioned rates, and as the foliar application method at 35 and 55 days from sowing at the previously mentioned concentration. The foliar treatments were carried out using had operated compressed air at the rate of 600 liter water/fad of each spraying date.

The experiments were laid out in split-split plot design in three replications. The main plots were assigned to nitrogen sources while sub plots were allocated to rates of nitrogen and the sub-sub plots were assigned to micro elements treatments. The sub-sub plot area was $10.5 \mathrm{~m} 2$ (3.5 m long x $3.0 \mathrm{~m}$ width).

Mechanical and chemical analysis of soil at the experimental sites are presented in Table 1.

The soil of the experiments was prepared as usual for maize and phosphorus fertilizer at the rate of $200 \mathrm{~kg}$ superphosphate/fad(15.5\% P2O5) and $100 \mathrm{~kg}$ of potassium sulphate $(48 \% \mathrm{~K} 2 \mathrm{O})$ was applied at the seed bed preparation. Seeds of maize (single hybrid10) were hand sown on 15th May in both 2002 and 2003 seasons. All the other recommended cutural practices for maize production were done. 


\section{El-Gharieb, A. E. et al.}

Data recorded:

1 -Ear length $(\mathrm{cm})$.

2-100 grain weight(g).

3-Stover yield per fad (ton).

4-Grain yield per fad (ardab).

5 -Protein percentage in grains, it was measured as a total $\mathrm{N}$ in grain sample

by Kieldahel Lechinque, Jackson (1973) and N \% multiplying 6.25.

Data were statistically analyzed according to the technique of analysis

of variance (ANOVA) and the lest significant difference (LSD) method was used to test the difference among the treatment means as published by Gomez and Gomez (1984).

Table(1):Mechanical and chemical analysis of the soil experimental sites

\begin{tabular}{|c|c|c|}
\hline \multirow{2}{*}{ Soil properties } & \multicolumn{2}{|c|}{ Season } \\
\hline & 2002 & 2003 \\
\hline \multicolumn{3}{|l|}{ Mechanical analysis } \\
\hline Coarse sand $\%$ & 10.44 & 15.50 \\
\hline Fine sand \% & 27.41 & 22.37 \\
\hline Silt $\%$ & 15.35 & 19.40 \\
\hline Clay & 46.80 & 42.73 \\
\hline Soil texture & Caly loam & Caly loam \\
\hline \multicolumn{3}{|l|}{ Chemical analysis } \\
\hline Ec $\quad(\mathrm{ds} / \mathrm{m})$ (soil paste textract) & 4.23 & 4.75 \\
\hline PH $\quad(1: 2.5$, Soil:water) & 7.95 & 8.45 \\
\hline CaCo3 \% & 5.60 & 5.20 \\
\hline O.M. & 1.31 & 1.67 \\
\hline \multicolumn{3}{|l|}{ Available nutrients (mg/kg) } \\
\hline $\begin{array}{ll}N & (p p m) \\
P & (p p m)\end{array}$ & $\begin{array}{l}19.00 \\
13.00\end{array}$ & $\begin{array}{l}15.00 \\
12.00\end{array}$ \\
\hline$K \quad$ (ppm) & 20.00 & 23.00 \\
\hline $\mathrm{Fe} \quad(\mathrm{ppm})$ & 2.10 & 1.10 \\
\hline $\mathrm{Zn}(\mathrm{ppm})$ & 0.40 & 0.31 \\
\hline
\end{tabular}

\section{RESULTS AND DISCUSSION}

Average ear length $(\mathrm{cm}), 100 \mathrm{grain}$ weight $(\mathrm{g})$, Stover yield (ton/fad), grain yield (ardab/fad) and protein percentage in grains of maize as affected by source, and rate of nitrogen and micro elements treatments in 2002 and 2003 seasons are shown in Tables 2,3,4,5 and 6. Results presented in Tables 2 to 6 show clearly that the effect of nitrogen source was significant on ear length, grain yield / fad and protein percentage in grain in both seasons, but it was significant on 100 grain weight (g) in 2002 season only and it was insignificant on stover yield / fad in both seasons. Applied ammonium gas as a source of nitrogen gave the highest values of ear length( 20.69 and 20.74 $\mathrm{cm}$ ), 100 grain weight( 34.11 and $33.35 \mathrm{~g}$ ), grain yield / fad (20.66 and 29.52 ardab) and protein percentage in grain (11.76 and $11.86 \%)$ as compared with nitrogen soruce of urea in 2002 and 2003 seasons, respectively. 
The increase in yield and yield components due to nitrogen source may be attributed to that ammonium gas which considered as nitrogen source can a rise physiological strategies such as increased dry matter production translocated and stored resulted in increasing ear length and $100 \mathrm{grain}$ weight increased. These results are in harmony with those of $\mathrm{El}$ Nemr et al. (1996), El-Sayed et al (1998), Khalifa and Zidan (1999), Osman et al (2001), Sarhan et al (2004) and Ragab and Ibrahim (2009a).

Results recorded in Tables 2 to 6 indicate that average values of ear length, 100 grain weight, stover and grain yield and protein percentage significantly affected by nitrogen fertilizer rate in both seasons. Increasing nitrogen rate from 100 to $140 \mathrm{~kg} \mathrm{~N} / \mathrm{fad}$ increased ear length by 7.31 and 7.35 $\%, 100$ grain weight by 1.82 and $2.22 \%$, stover yield by 5.44 and $7.02 \%$, grain yield by 7.81 and $8.68 \%$ and protein percentage in grain of maize by $5.77 \%$ and $5.15 \%$ in 2002 and 2003 seasons, respectively.

The increment of grain yield according to increasing nitrogen rate might be attributed to the active effect of nitrogen in raising photosynthesis which led to increasing yield components such as ear length and 100 grain weight resulted in increasing grain yield, also increased nitrogen uptake and stored in grains, hence increasing protein \% in grain of maize. These results are in agreement with those of El-Agamy et al. (1999), Allam et al .(2001),El-Bana (2001), Mohamed (2004), Gebraiel

et al .(2005), Leilah et al .(2009) and Nawar et al .(2009).

Results recorded in Tables 2-6 reveal that micro elements had a significant effect on all previously mentioned characters in both seasons. Also results indicated that application micro elements as a foliar application gave the highest values of all studied charaeter as compared with soil application in both seasons. Sprayed maize plants with mixed from micro elements $(\mathrm{Fe}+\mathrm{Zn})$ as a foliar application method gave the highest values of ear length (20.88 and $20.89 \mathrm{~cm}$ ), 100 grain weight( 34.64 and $34.22 \mathrm{~g}$ ),stover yield / fad( 3.61 and 3.76 ton), grain yield / $\mathrm{fad}(27.93$ and $30.67 \mathrm{ardab})$ and protein \% (12.00 and 12.09) as compared with all other micro elements treatments in 2002 and 2003 seasons, respectively. These results are in agreement with those Abdel Messih et al .(1999),Omran (2000), Osman et al .(2001), El- Akbawy et al .(2001), El - Nagar (2002) and Darwish (2003).

The increase in grain yield and its components owing to micro elements $(\mathrm{Fe}+\mathrm{Zn})$ may be due to the effect of $\mathrm{Zn}$ in the formation and the activity of the enzyme responsible for protein synthesis. Also Zinc enhanced plant growth and improve transferring the photosynthetic substances from leaves to grains during synthesis process because of their effect the engymatic group, therefor increasing ear length (Table 2 ), 100 grain weight (Table 3 ), stover yield (Table 4 ), grain yield (Table 5 ) and protein percentage (Table 6 ). These results are in harmony with those of Omran (2000), Osman et al .(2001), El-Nagar (2002), He et al .(2002), Darwish (2003) and Zein et al .(2009). 
EI-Gharieb, A. E. et al.

2 
J. Plant Production, Mansoura Univ., Vol. 2 (3), March, 2011

3 
EI-Gharieb, A. E. et al.

4 
J. Plant Production, Mansoura Univ., Vol. 2 (3), March, 2011

5 
EI-Gharieb, A. E. et al.

6 
The obtained results showed that the interaction effect between nitrogen source and nitrogen rate was significant on grain yield / fad and protein percentage in grain of maize in both seasons, but it had a significant effect on ear length in the second season only. On the other hand , 100 grain weight and stover yield / fad insignificantly affected in both seasons. The tallest ear of maize plants 21.67 was found with applied ammonia gas at the rate of 140 $\mathrm{kg} \mathrm{N} / \mathrm{fad}$ compared to other this interaction treatments in 2003 season. In this connection plants received nitrogen fertilizer at the rate of $140 \mathrm{~kg} \mathrm{~N} / \mathrm{fad}$ in the form of ammonia gas gave the highest grain yield / fad (27.42 and 30.92 ardab) and protein percentage (11.95 and $12.05 \%$ ) compared to all other interaction treatments in 2002 and 2003 seasons, respectively.

It can be seen from results recorded in Tables 2 to 6 that the interaction effect among nitrogen source and micro elements treatments was insignificant on ear length, 100 grain weight and stover yield / fad in both seasons, and on protein percentage in 2003 season. On the contrary it was significant on grain yield / fad in both seasons and protein \% in the first season. However, plants grown under soil injected by ammonia gas and sprayed with mixed from micro element $(\mathrm{Fe}+\mathrm{Zn})$ as a foliar application gave the highest grain yield / fad (28.63 and 31.34 ardab) and protein percentage (12.09 and $12.09 \%$ ) compared to all other this interaction treatments in 2002 and 2003 seasons, respectively.

Results tabulated in Tables 2 to 6 reveal that the interaction effect between nitrogen rate and micro elements treatments was significant on ear length in the secand season as well as on grain yield /fad and protein percentage in both seasons. On the other hand it was insignificant on 100 grain weight and stover yield / fad in both seasons. Generally, maize plants fertilized by $140 \mathrm{~kg} \mathrm{~N} / \mathrm{fad}$ and sprayed with micro element mixed ( $\mathrm{Fe}+\mathrm{Zn})$ as a foliar application method gave the tallest ear $(21.69$ and $21.70 \mathrm{~cm})$, grain yield / fad (29.07 and 31.96 ardab) and protein \% (12.22 and $12.26 \%$ ) as compared with all other this interaction treatments in 2002 and 2003 seasons, respectively.

Results recorded in Tables 2 to 6 indicate that the interaction effect between nitrogen source, nitrogen rate and micro element treatments was insignificant on all characters studied in both seasons, except ear length in the second season and grain yield /fad in both seasons. Decidedly, plants received nitrogen fertilizer at the rate of $140 \mathrm{~kg} \mathrm{~N} / \mathrm{fad}$ in the from of ammonia gas as sprayed by mixed from micro elements $(\mathrm{Fe}+\mathrm{Zn})$ gave the highest ear length (22.17 and $22.20 \mathrm{~cm}$ ) grain yield / fad (29.35 and 32.49 ardab) as compared with all other this interaction treatments in 2002 and 2003 seasons, respectively.

Generally, it could be recommended that applying of ammonia gas at the rate of $140 \mathrm{~kg} \mathrm{~N} / \mathrm{fad}$ and sprayed with mixed from $\mathrm{Fe}+\mathrm{Zn}$ of micro elements greatest grain yield / fad of maize grown under salt affected soil at FI-Faiyoum Governorate conditions. 


\section{REFERENCES}

Abdel Messih, S. G.; A. Sh. Abdel Nour and A.I. El-Shafie. (1999). Response of yellow maize to foliar spray of micronutrients withdifferent acidity solutions under various nitrogen levels. Egypt. J. Appl. Sci, 14 (6) : 140-152.

Allam, S. M. M.; A. S. Osman.; M. Y. Gbraiel and G. M. ElShebing.(2001). Effect of nitrogen rates and foliar application of zinc and boron on maize. Egypt. J. Appl. Sei.,16:161-168.

Darwish, A.A.(2003). The yield and yield components of maize as influenced by nitrogen, zinc and boron fertilization. J. Agric. Sci. Mansoura Univ., 28 (2) : 799-810.

El-Agamy, A. I.; G. A. Morshed.; F. H. Soliman and M. K. H. Osman. (1999).Performance of some yellow maize hybrids under different plant population densities and nitrogen fertilizer levels. J. Agric. Sci. Mansoura Univ., 24 (3) : 911- 923.

El- Akabawy, M.A.; H. G. Abu El- Fotoh, A. A. Abd El- Magid and Nadia, O. Monged .(2001). Effect of organic and inorganic fertilization on yield and grain mineral content of Zea mays on clay soil of Nil delta. Egypt. J. Appl. Sci, 16 (9) : 300-308.

El-Bana, A.Y.A. (2001). Effect of nitrogen fertilization and stripping leaves on yield and yield attributes of two maize (Zea mays,L.)Hybrids.Zagazig.JAgric. Res., 28 (3): 579-596.

El-Nagar,G.R.(2002).Effect of nitrogen fertilizer and foliar application with micronutrients on white and yellow maize. Assiut. J. Agric. Res., 33 (3): 85-102.

El-Nemr ,Hanyat, M.; A. Y. Negm.; Khadra, A. Abbady and I. A. I. Mousa. (1996).and insecticides in calcareous soils and their residual effect on flax. Egypt. J. Agric. Res., 74 (1) : 1-13.

El-Sayed, E.A.; D. S. Darwish and N. S. Rezike. (1998). Effect of nitrogenforms application on the yield and quality of corn plants grown under El- Faiyoum conditions. Faiyoum J. Agric. Res.And Dev., 12 (1): 205- 216.

Gebraiel, M.Y.; M. N. Gohar.; F. S. Salem and H.W.A.Wahba. (2005).Vegetative growth and yield of maize (Zea mays, L.) as affected by nitrogen, potassium and zinc fertilization. Egypt. J. Appl. Sci. 20(2b): 739-755.

Gomes, K.A. and A. A. Gomes. (1984). Statistical procedures for Agricultural research. 2nd Ed. PP. 680. John Wiley and Sons, New York, U.S.A.

Hammam, G.Y. (1995). Growth and yield of maize (Zea mays, L.) as affected by nitrogen source and time of application. Annals of Agric. Sci. Moshtohor, 33(2) : 483-494. 
He-Tianxui.; Wu-Deyi.; He-Chenghui.; Tu-Shihua.; Wu-Guangquan.; WuWangcheng.; Kong- Sheng.; Wang- Jipeng.; He-Tx.; Wu-D.; He-Ch.; Tu-Sh.; Wu-Go.; Wu-Wc.; Kong- S and Wang- J.P. (2002). Fertilization for high yield in corn - sweet potato- Wheat rotation: a systematic approach to nutrient limiting factors of soils in Chonging, China. Pedosphere. 12(3):265-274.

Jackson, M.L.(1973).Soil chemical Analysis Prentice - Hall of India, Private Limited, New Delhi.

Khalifa, K and Zidan,A.(1999). Effect of nitrate addition on efficient use of ammonium sulfate fertilizer on corn under saline conditions. I. Pot experiment. Communications in soil science and plant Analysis, 30 (1516): 2145-2156.

Leilah, A.A.; M. A. Badawi; M.I.El-Emery and Rasha, S.A. El-Moursy. (2009). Effect of plant population, organic fertilization and nitrogen levels on growth and yield of maize. J. Agric. Sci. Mansoura Univ., 34(2)12531264.

Mohamed, N.A.(2004). Principal component and response curve analyses of some maize hybrids to different nitrogen fertilization levels and plant density. Bull. Fac.Agric., Cairo Univ., 55 : 531-556.

Nawar, A.I.;I.E.Mohamadein , and H.E.Khalil.(2009).Response of maize to fertilization and rotational crop sequences. Alex. J. Agric. Res.Vol. 54,No.3,pp.29-39.

Omran, A.A. (2000). Foliar application of some zinc sources for corn crop. Egypt . J. Appl. Sci.,15 (1) : 305- 315.

Osman, A.S.;S. M. M. Allam.; G. M. El-Shebing and M.Y. Gebrail. (2001).Influence of nitrogen and micronutrient sources on maize plants. Egypt. J. Appl. Sci., 16 (4) : 150-160.

Ragab, A.Y. and M. H. Ibrahim.(2009a). Effect of nitrogen, phosphorus and biofertilizers on maize : 1-Growth traits. J. Agric. Sci. Mansoura Univ., 34 (7): 8027-8042.

Ragab, A.Y. and M. H. Ibrahim. (2009b). Effect of nitrogen, phosphorus and biofertilizers on maize : 2-Yield and its components. J. Agric. Sci. Mansoura Univ. 34 (7) : 8043-8054.

Sarhan, S.H.; M. R. Mohamed.; H. Z. Abd El-Salam and M.M. A. Bader. (2004).Influence of nitrogen sources on growth, yield, some macro and micronutrients content of maize plant (Zea mays, L.) in salt affected soils. J.Agric. Sci. Mansoura Univ., (3) : 1589- 1601.

Zein, F. I.; Asmaa. A. El-Basuony and H. S. Hamoud. (2009). Maizeresponse to zinc application under different phosphorus fertilization levels, its nutrients uptake, and availability in allouvial soils. J. Agric. Sci. Mansoura Univ., 34(5) : 5683-5704. 


\section{El-Gharieb, A. E. et al.}

" تاثير مصدر ومعدل النتروجين وبعض معاملات العناصر الصغرى على ناتج الذرة

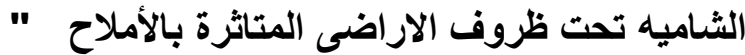

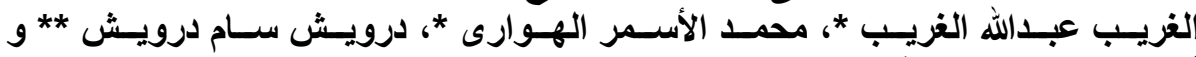

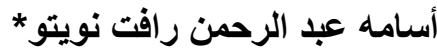

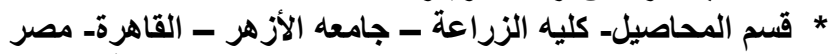

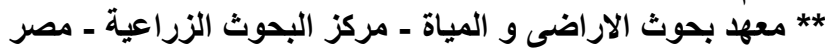

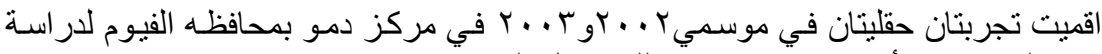

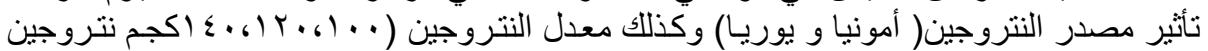

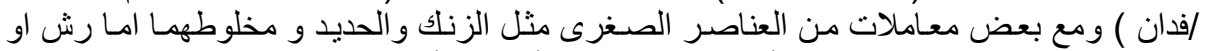

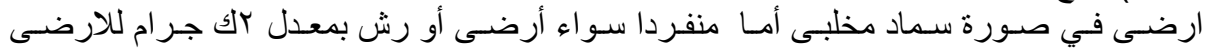

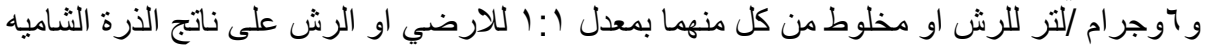

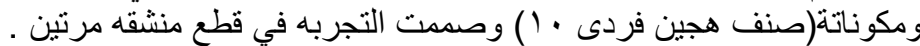

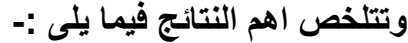

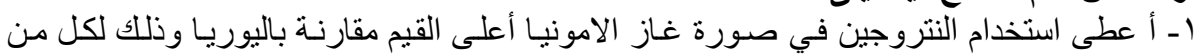

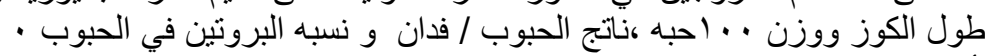

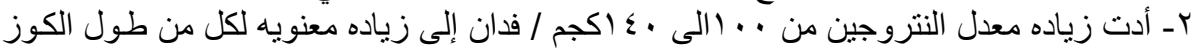

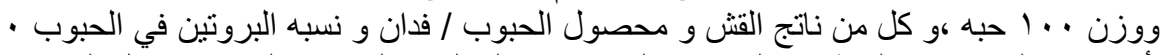

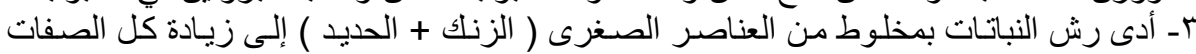

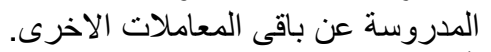

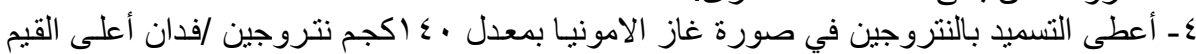

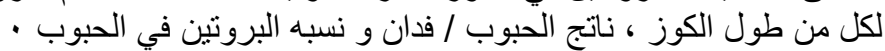

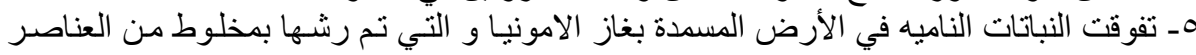

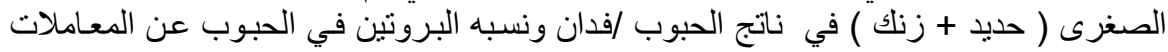

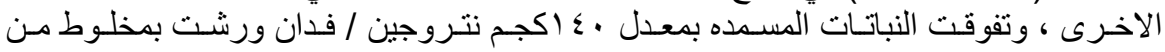

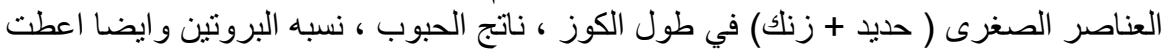

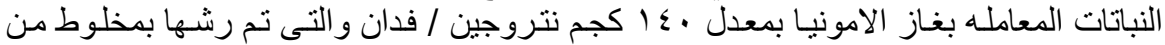

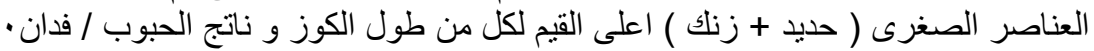

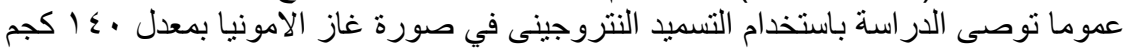

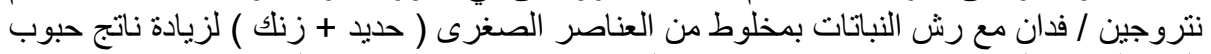
الذرة الثاميه الناميه تحت ظروف النات بار اضى المناثرة بالاملاح في محافظه الفيوم ل

كلية الزراعة - جامعة المنصورة كلية الزراعة - جامعة الاز هر المرور 
J. Plant Production, Mansoura Univ., Vol. 2 (3), March, 2011 
J. Plant Production, Mansoura Univ., Vol. 2 (3): 521 - 534, 2011

Table 2 : Average ear length $(\mathrm{cm})$ of maize as affected by nitrogen source and rate as well as some micro element treatments in 2002 and 2003 seasons.

\begin{tabular}{|c|c|c|c|c|c|c|c|c|c|c|c|c|c|c|c|}
\hline \multirow{3}{*}{$\begin{array}{c}\text { N.sources } \\
\text { (S) }\end{array}$} & \multirow{3}{*}{$\begin{array}{l}\text { N.rate } \\
\mathrm{Kg} / \mathrm{fad} \\
(\mathrm{N})\end{array}$} & \multicolumn{7}{|c|}{2002 Season } & \multicolumn{7}{|c|}{2003 Season } \\
\hline & & \multicolumn{7}{|c|}{ Micronutrient treatments(M) } & \multicolumn{7}{|c|}{ Micronutrient treatments(M) } \\
\hline & & $F(F)$ & $\mathrm{Zn}(\mathrm{F})$ & $\begin{array}{c}\operatorname{Mixed}(F) \\
(F e+Z n) \\
\end{array}$ & $\mathrm{Fe}(\mathrm{s})$ & $\mathrm{Zn}(\mathrm{s})$ & $\begin{array}{c}\operatorname{Mixed}(\mathbf{s}) \\
(\mathrm{Fe}+\mathrm{ZN}) \\
\end{array}$ & Mean & $F(F)$ & $\mathrm{Zn}(\mathrm{F})$ & \begin{tabular}{|c|} 
Mixed(F) \\
$(\mathrm{Fe}+\mathrm{Zn})$ \\
\end{tabular} & $\mathrm{Fe}(\mathbf{s})$ & $\mathrm{Zn}(\mathrm{s})$ & $\begin{array}{c}\text { Mixed(s) } \\
(\mathrm{Fe}+\mathrm{Zn}) \\
\end{array}$ & Mean \\
\hline \multirow{4}{*}{ Ammonia } & 100 & 19.83 & 20.33 & 20.33 & 19.50 & 19.83 & 20.00 & 19.97 & 20.00 & 20.33 & 20.33 & 19.53 & 19.87 & 20.03 & 20.02 \\
\hline & 120 & 19.97 & 20.83 & 21.23 & 19.70 & 20.43 & 20.83 & 20.50 & 20.00 & 21.00 & 21.23 & 19.73 & 20.43 & 20.87 & 20.54 \\
\hline & 140 & 21.83 & 21.83 & 22.17 & 21.17 & 21.20 & 21.40 & 21.60 & 21.97 & 22.00 & 22.20 & 21.20 & 21.23 & 21.43 & 21.67 \\
\hline & mean & 20.54 & 21.00 & 21.24 & 20.12 & 20.49 & 20.74 & 20.69 & 20.66 & 21.11 & 21.25 & 20.15 & 20.51 & 20.78 & 20.74 \\
\hline \multirow{4}{*}{ Urea } & 100 & 19.17 & 19.77 & 20.00 & 18.93 & 19.23 & 19.33 & 19.41 & 19.27 & 19.77 & 20.03 & 18.97 & 19.27 & 19.33 & 19.44 \\
\hline & 120 & 19.57 & 19.90 & 20.33 & 19.17 & 19.68 & 19.77 & 19.74 & 19.60 & 19.90 & 20.37 & 19.20 & 19.68 & 19.77 & 19.75 \\
\hline & 140 & 20.50 & 20.93 & 21.20 & 19.77 & 20.53 & 20.93 & 20.64 & 20.60 & 21.00 & 21.20 & 19.80 & 20.57 & 20.97 & 20.69 \\
\hline & mean & 19.75 & 20.20 & 20.51 & 19.29 & 19.81 & 20.01 & 19.93 & 19.82 & 20.22 & 20.53 & 19.32 & 19.84 & 20.02 & 19.96 \\
\hline \multirow{4}{*}{\begin{tabular}{|l|} 
General \\
means \\
N. rate \\
General m \\
\end{tabular}} & 100 & 19.50 & 20.05 & 20.17 & 19.22 & 19.53 & 19.67 & 19.69 & 19.64 & 20.05 & 20.18 & 19.25 & 19.57 & 19.68 & 19.73 \\
\hline & $f 120$ & 19.77 & 20.37 & 20.78 & 19.44 & 20.06 & 20.30 & 20.12 & 19.80 & 20.45 & 20.80 & 19.47 & 20.06 & 20.32 & 20.15 \\
\hline & 140 & 21.17 & 21.38 & 21.69 & 20.47 & 20.87 & 21.17 & 21.13 & 21.29 & 21.50 & 21.70 & 20.50 & 20.90 & 21.20 & 21.18 \\
\hline & ean & 20.15 & 20.60 & 20.88 & 19.71 & 20.15 & 20.38 & & 20.24 & 20.67 & 20.89 & 19.74 & 20.18 & 20.40 & \\
\hline
\end{tabular}

General mean

(S)Soil application method

(F)Foliar application method

L.S.D at 0.05 for:

$\begin{array}{lcc}\text { Sources } & (\mathrm{S}) & * \\ \text { N. Rate } & (\mathrm{N}) & 0.26 \\ \text { Micro element } & \text { (M) } & 0.23 \\ \text { Interaction } & \text { SN } & \text { N.S } \\ \text { Interaction } & \text { SM } & \text { N.S } \\ \text { Interaction } & \text { NM } & \text { N.S } \\ \text { Interaction } & \text { SNM } & \text { N.S }\end{array}$

Micro element

Interaction

SNM 
J. Plant Production, Mansoura Univ., Vol. 2 (3), March, 2011

Table 3: Average 100 grain weight $(\mathrm{g})$ of maize as affected by nitrogen source and rate as well as some micro element treatments in 2002 and 2003 seasons.

\begin{tabular}{|c|c|c|c|c|c|c|c|c|c|c|c|c|c|c|c|}
\hline \multirow{3}{*}{$\begin{array}{c}\text { N.sources } \\
\text { (S) }\end{array}$} & \multirow{3}{*}{$\begin{array}{l}\text { N.rate } \\
\mathrm{Kg} / \mathrm{fad} \\
(\mathrm{N})\end{array}$} & \multicolumn{7}{|c|}{2002 Season } & \multirow{2}{*}{\multicolumn{7}{|c|}{$\begin{array}{c}2003 \text { Season } \\
\text { Micronutrient treatments(M) }\end{array}$}} \\
\hline & & \multicolumn{7}{|c|}{ Micronutrient treatments(M) } & & & & & & & \\
\hline & & $F(F)$ & $\mathrm{Zn}(\mathrm{F})$ & $\begin{array}{c}\text { Mixed(F) } \\
(\mathrm{Fe}+\mathrm{Zn})\end{array}$ & $\mathrm{Fe}(\mathbf{s})$ & $\mathrm{Zn}(\mathbf{s})$ & \begin{tabular}{|c|} 
Mixed(s) \\
$(F e+Z n)$
\end{tabular} & Mean & $F(F)$ & $\mathrm{Zn}(\mathrm{F})$ & \begin{tabular}{|c|} 
Mixed(F) \\
$(\mathrm{Fe}+\mathrm{Zn})$
\end{tabular} & $\mathrm{Fe}(\mathbf{s})$ & $\mathrm{Zn}(\mathrm{s})$ & $\begin{array}{c}\text { Mixed(s) } \\
(\mathrm{Fe}+\mathrm{Zn})\end{array}$ & Mean \\
\hline \multirow{4}{*}{ Ammonia } & 100 & 33.23 & 34.00 & 34.60 & 33.13 & 33.67 & 34.37 & 33.83 & 32.13 & 33.13 & 34.00 & 31.90 & 33.00 & 33.90 & 33.01 \\
\hline & 120 & 33.47 & 34.23 & 34.90 & 33.73 & $33 . .93$ & 34.63 & 34.15 & 32.23 & 33.03 & 34.40 & 32.50 & 33.23 & 34.43 & 33.30 \\
\hline & 140 & 33.87 & 34.47 & 35.23 & 33.63 & 34.20 & 34.97 & 34.40 & 33.37 & 33.43 & 34.67 & 33.00 & 33.47 & 34.57 & 33.75 \\
\hline & mean & 33.52 & 34.23 & 34.91 & 33.38 & 33.93 & 34.66 & 34.11 & 32.58 & 33.20 & 34.36 & 32.47 & 33.23 & 34.30 & 33.35 \\
\hline \multirow{4}{*}{ Urea } & 100 & 32.87 & 33.40 & 34.17 & 32.63 & 33.10 & 33.70 & 33.31 & 32.10 & 32.90 & 33.90 & 31.87 & 32.67 & 33.50 & 32.82 \\
\hline & 120 & 33.33 & 33.73 & 34.13 & 33.00 & 33.47 & 33.83 & 33.58 & 32.60 & 33.27 & 33.83 & 32.40 & 33.23 & 33.63 & 33.16 \\
\hline & 140 & 33.73 & 33.90 & 34.77 & 33.50 & 33.77 & 34.17 & 33.97 & 32.87 & 33.57 & 34.50 & 32.93 & 33.43 & 33.97 & 33.55 \\
\hline & mean & 33.31 & 33.68 & 34.36 & 33.04 & 33.45 & 33.90 & 33.62 & 32.52 & 33.25 & 34.08 & 32.40 & 33.11 & 33.70 & 33.18 \\
\hline \multirow{4}{*}{$\begin{array}{l}\text { General } \\
\text { means o } \\
\text { N. rate }\end{array}$} & 100 & 33.05 & 33.70 & 34.39 & 32.88 & 33.39 & 34.04 & 33.58 & 32.12 & 33.02 & 33.95 & 31.89 & 32.84 & 33.70 & 32.92 \\
\hline & 120 & 33.40 & 33.98 & 34.52 & 33.19 & 33.70 & 34.23 & 33.84 & 32.42 & 33.15 & 34.12 & 32.45 & 33.23 & 34.03 & 33.23 \\
\hline & 140 & 33.80 & 34.19 & 35.00 & 33.57 & 33.99 & 34.57 & 34.19 & 33.12 & 33.50 & 34.59 & 32.97 & 33.45 & 34.27 & 33.65 \\
\hline & General mean & 33.42 & 33.96 & 34.64 & 33.21 & 33.59 & 34.28 & & 32.55 & 33.23 & 34.22 & 32.44 & 33.17 & 34.00 & \\
\hline
\end{tabular}

S)Soil application method

(F)Foliar application method

L.S.D at 0.05 for:

$\begin{array}{lcc}\text { Sources } & (\mathrm{S}) & * \\ \text { N. Rate } & \text { (N) } & 0.13 \\ \text { Micro elements } & \text { (M) } & 0.21 \\ \text { Interaction } & \text { SN } & \text { N.S } \\ \text { Interaction } & \text { SM } & \text { N.S } \\ \text { Interaction } & \text { NM } & \text { N.S } \\ \text { Interaction } & \text { SNM } & \text { N.S }\end{array}$


El-Gharieb, A. E. et al.

Table 4: Average stover yield(ton/fad) of maize as affected by nitrogen source and rate as well as some micro element treatments in 2002 and 2003 seasons.

\begin{tabular}{|c|c|c|c|c|c|c|c|c|c|c|c|c|c|c|c|}
\hline \multirow{3}{*}{$\begin{array}{c}\text { N.sources } \\
\text { (S) }\end{array}$} & \multirow{3}{*}{$\begin{array}{l}\text { N.rate } \\
\mathrm{Kg} / \mathrm{fad} \\
(\mathrm{N})\end{array}$} & \multicolumn{7}{|c|}{2002 Season } & \multicolumn{7}{|c|}{2003 Season } \\
\hline & & \multicolumn{7}{|c|}{ Micronutrient treatments(M) } & \multicolumn{7}{|c|}{ Micronutrient treatments(M) } \\
\hline & & $F(F)$ & $\mathrm{Zn}(\mathrm{F})$ & $\begin{array}{c}\operatorname{Mixed}(F) \\
(F e+Z n) \\
\end{array}$ & $\mathrm{Fe}(\mathbf{s})$ & $\mathrm{Zn}(\mathbf{s})$ & $\begin{array}{c}\text { Mixed(s) } \\
(\mathrm{Fe}+\mathrm{Zn})\end{array}$ & Mean & $F(F)$ & $\mathrm{Zn}(\mathrm{F})$ & \begin{tabular}{|c|}
$\operatorname{Mixed}(\mathrm{F})$ \\
$(\mathrm{Fe}+\mathrm{Zn})$ \\
\end{tabular} & $\mathrm{Fe}(\mathbf{s})$ & $\mathrm{Zn}(\mathrm{s})$ & $\begin{array}{c}\text { Mixed(s) } \\
(\mathrm{Fe}+\mathrm{Zn}) \\
\end{array}$ & Mean \\
\hline \multirow{4}{*}{ Ammonia } & 100 & 3.18 & 3.51 & 3.58 & 3.12 & 3.35 & 3.47 & 3.37 & 3.30 & 3.60 & 3.70 & 3.20 & 3.45 & 3.60 & 3.48 \\
\hline & 120 & 3.27 & 3.59 & 3.60 & 3.14 & 3.45 & 3.50 & 3.43 & 3.50 & 3.65 & 3.80 & 3.43 & 3.60 & 3.75 & 3.62 \\
\hline & 140 & 3.34 & 3.65 & 3.68 & 3.25 & 3.57 & 3.67 & 3.53 & 3.70 & 3.75 & 3.90 & 3.50 & 3.70 & 3.80 & 3.73 \\
\hline & mean & 3.26 & 3.58 & 3.62 & 3.17 & 3.46 & 3.55 & 3.44 & 3.50 & 3.67 & 3.80 & 3.38 & 3.58 & 3.72 & 3.61 \\
\hline \multirow{4}{*}{ Urea } & 100 & 3.03 & 3.37 & 3.52 & 2.95 & 3.20 & 3.38 & 3.24 & 3.20 & 3.50 & 3.65 & 3.00 & 3.35 & 3.50 & 3.37 \\
\hline & 120 & 3.20 & 3.52 & 3.53 & 3.08 & 3.33 & 3.45 & 3.35 & 3.40 & 3.55 & 3.73 & 3.30 & 3.40 & 3.55 & 3.49 \\
\hline & 140 & 3.33 & 3.53 & 3.73 & 3.17 & 3.43 & 3.52 & 3.45 & 3.50 & 3.60 & 3.75 & 3.40 & 3.55 & 3.70 & 3.58 \\
\hline & mean & 3.19 & 3.47 & 3.59 & 3.07 & 3.32 & 3.45 & 3.35 & 3.37 & 3.55 & 3.71 & 3.23 & 3.43 & 3.58 & 3.48 \\
\hline \multirow{4}{*}{\begin{tabular}{|l|} 
General \\
means of \\
N. rate \\
General me \\
\end{tabular}} & 100 & 3.11 & 3.44 & 3.55 & 3.04 & 3.28 & 3.43 & 3.31 & 3.25 & 3.55 & 3.68 & 3.10 & 3.40 & 3.55 & 3.42 \\
\hline & 120 & 3.24 & 3.56 & 3.57 & 3.11 & 3.39 & 3.48 & 3.39 & 3.45 & 3.60 & 3.77 & 3.37 & 3.50 & 3.65 & 3.56 \\
\hline & 140 & 3.34 & 3.59 & 3.71 & 3.21 & 3.50 & 3.60 & 3.49 & 3.60 & 3.68 & 3.83 & 3.45 & 3.63 & 3.75 & 3.66 \\
\hline & lean & 3.23 & 3.53 & 3.61 & 3.12 & 3.39 & 3.50 & & 3.43 & 3.61 & 3.76 & 3.31 & 3.51 & 3.65 & \\
\hline
\end{tabular}

(S)Soil application method

(F)Foliar application method

L.S.D at 0.05 for:

$\begin{array}{lcc}\text { Sources } & \text { (S) } & \text { N.S } \\ \text { N. Rate } & \text { (N) } & 0.06 \\ \text { Micro element } & \text { (M) } & 0.11 \\ \text { Interaction } & \text { SN } & \text { N.S } \\ \text { Interaction } & \text { SM } & \text { N.S } \\ \text { Interaction } & \text { NM } & \text { N.S } \\ \text { Interaction } & \text { SNM } & \text { N.S }\end{array}$

N.S

0.10

0.14

Interaction

SNM

N.S

N.S 
J. Plant Production, Mansoura Univ., Vol. 2 (3), March, 2011

Table 5: Average grain yield per fad (ardab) of maize as affected by nitrogen source and rate as well as some micro element treatments in 2002 and 2003 seasons.

\begin{tabular}{|c|c|c|c|c|c|c|c|c|c|c|c|c|c|c|c|}
\hline \multirow{3}{*}{$\begin{array}{c}\text { N.sources } \\
\text { (S) }\end{array}$} & \multirow{3}{*}{$\mid \begin{array}{l}\text { N.rate } \\
\mathrm{Kg} / \mathrm{fad} \\
(\mathrm{N})\end{array}$} & \multicolumn{7}{|c|}{2002 Season } & \multicolumn{7}{|c|}{2003 Season } \\
\hline & & \multicolumn{7}{|c|}{ Micronutrient treatments(M) } & \multicolumn{7}{|c|}{ Micronutrient treatments(M) } \\
\hline & & $F(F)$ & $\mathrm{Zn}(\mathrm{F})$ & $\begin{array}{c}\operatorname{Mixed}(\mathrm{F}) \\
(\mathrm{Fe}+\mathrm{Zn}) \\
\end{array}$ & $\mathrm{Fe}(\mathrm{s})$ & $\mathrm{Zn}(\mathrm{s})$ & \begin{tabular}{|c|} 
Mixed(s) \\
$(\mathrm{Fe}+\mathrm{Zn})$ \\
\end{tabular} & Mean & $F(F)$ & $\mathrm{Zn}(\mathrm{F})$ & \begin{tabular}{|c|} 
Mixed(F) \\
$(F e+Z n)$ \\
\end{tabular} & $\mathrm{Fe}(\mathrm{s})$ & $\mathrm{Zn}(\mathrm{s})$ & \begin{tabular}{|c} 
Mixed(s) \\
$(\mathrm{Fe}+\mathrm{Zn})$ \\
\end{tabular} & Mean \\
\hline \multirow{4}{*}{ Ammonia } & 100 & 25.13 & 26.06 & 28.11 & 24.28 & 25.13 & 27.13 & 25.97 & 27.50 & 28.56 & 29.99 & 27.13 & 27.85 & 28.56 & 28.27 \\
\hline & 120 & 26.13 & 26.56 & 28.42 & 25.06 & 25.92 & 27.49 & 26.60 & 27.85 & 29.99 & 31.55 & 27.49 & 28.56 & 30.70 & 29.69 \\
\hline & 140 & 26.77 & 27.27 & 29.35 & 25.85 & 26.70 & 28.56 & 27.42 & 28.56 & 32.13 & 32.49 & 28.56 & 31.63 & 32.13 & 30.92 \\
\hline & mean & 26.01 & 26.63 & 28.63 & 25.06 & 25.92 & 27.73 & 26.66 & 27.97 & 30.23 & 31.34 & 27.73 & 29.35 & 30.46 & 29.52 \\
\hline \multirow{4}{*}{ Urea } & 100 & 23.78 & 24.63 & 25.71 & 22.64 & 23.35 & 24.99 & 24.18 & 25.70 & 27.85 & 28.56 & 25.70 & 26.42 & 27.85 & 27.01 \\
\hline & 120 & 24.35 & 25.42 & 27.20 & 23.61 & 24.42 & 25.85 & 25.14 & 26.77 & 28.56 & 29.99 & 26.42 & 27.49 & 28.20 & 27.91 \\
\hline & 140 & 25.78 & 26.56 & 28.78 & 24.99 & 25.99 & 27.84 & 26.66 & 27.85 & 29.99 & 31.42 & 27.13 & 28.56 & 29.99 & 29.16 \\
\hline & mean & 24.64 & 25.54 & 27.23 & 23.75 & 24.59 & 26.23 & 25.33 & 26.77 & 28.80 & 29.99 & 26.42 & 27.49 & 28.68 & 28.03 \\
\hline \multirow{4}{*}{\begin{tabular}{|l}
$\begin{array}{l}\text { General } \\
\text { means of } \\
\text { N. rate }\end{array}$ \\
General me \\
\end{tabular}} & 100 & 24.46 & 25.35 & 26.91 & 23.46 & 24.24 & 26.06 & 25.08 & 26.60 & 28.21 & 29.28 & 26.42 & 27.14 & 28.21 & 27.64 \\
\hline & 120 & 25.24 & 25.99 & 27.81 & 24.34 & 25.17 & 26.67 & 25.87 & 27.31 & 29.28 & 30.77 & 26.96 & 28.03 & 29.45 & 28.80 \\
\hline & 140 & 26.28 & 26.92 & 29.07 & 25.42 & 26.35 & 28.20 & 27.04 & 28.21 & 31.06 & 31.96 & 27.85 & 30.10 & 31.06 & 30.04 \\
\hline & lean & 25.33 & 26.09 & 27.93 & 24.41 & 25.25 & 26.98 & & 27.37 & 29.52 & 30.67 & 27.08 & 28.42 & 29.57 & \\
\hline
\end{tabular}

(S)Soil application method

(F) Foliar application method

L.S.D at 0.05 for:

$\begin{array}{lcc}\text { Sources } & \text { (S) } & * \\ \text { N. Rate } & \text { (N) } & 0.29 \\ \text { Micro element } & \text { (M) } & 0.31 \\ \text { Interaction } & \text { SN } & 0.41 \\ \text { Interaction } & \text { SM } & 0.44 \\ \text { Interaction } & \text { NM } & 0.54 \\ \text { Interaction } & \text { SNM } & 0.77\end{array}$


El-Gharieb, A. E. et al.

Table 6: Average of protein percentage of grain of maize as affected by nitrogen source and rate as well as some micro element treatments in 2002 and 2003 seasons.

\begin{tabular}{|c|c|c|c|c|c|c|c|c|c|c|c|c|c|c|c|}
\hline \multirow{3}{*}{$\begin{array}{c}\text { N.sources } \\
\text { (S) }\end{array}$} & \multirow{3}{*}{$\begin{array}{l}\text { N.rate } \\
\mathrm{Kg} / \mathrm{fad} \\
(\mathrm{N})\end{array}$} & \multicolumn{7}{|c|}{2002 Season } & \multicolumn{7}{|c|}{2003 Season } \\
\hline & & \multicolumn{7}{|c|}{ Micronutrient treatments(M) } & \multicolumn{7}{|c|}{ Micronutrient treatments(M) } \\
\hline & & $F(F)$ & $\mathrm{Zn}(\mathrm{F})$ & $\begin{array}{c}\operatorname{Mixed}(F) \\
(F e+Z n) \\
\end{array}$ & $\mathrm{Fe}(\mathrm{s})$ & $\mathrm{Zn}(\mathbf{s})$ & $\begin{array}{c}\text { Mixed(s) } \\
(\mathrm{Fe}+\mathrm{Zn})\end{array}$ & Mean & $F(F)$ & $\mathrm{Zn}(\mathrm{F})$ & \begin{tabular}{|c|}
$\operatorname{Mixed}(\mathrm{F})$ \\
$(\mathrm{Fe}+\mathrm{Zn})$ \\
\end{tabular} & $\mathrm{Fe}(\mathbf{s})$ & $\mathrm{Zn}(\mathrm{s})$ & $\begin{array}{c}\text { Mixed(s) } \\
(\mathrm{Fe}+\mathrm{Zn}) \\
\end{array}$ & Mean \\
\hline \multirow{4}{*}{ Ammonia } & 100 & 11.19 & 11.50 & 11.94 & 10.94 & 11.56 & 11.88 & 11.50 & 11.25 & 11.88 & 11.87 & 11.06 & 11.88 & 11.94 & 11.65 \\
\hline & 120 & 11.75 & 11.88 & 12.13 & 11.56 & 11.69 & 11.88 & 11.82 & 11.75 & 11.88 & 12.15 & 11.56 & 11.88 & 12.00 & 11.87 \\
\hline & 140 & 11.88 & 12.19 & 12.19 & 11.56 & 11.88 & 12.00 & 11.95 & 12.00 & 12.00 & 12.24 & 11.88 & 12.19 & 12.00 & 12.05 \\
\hline & mean & 11.61 & 11.86 & 12.09 & 11.35 & 11.71 & 11.92 & 11.76 & 11.67 & 11.92 & 12.09 & 11.50 & 11.98 & 11.98 & 11.86 \\
\hline \multirow{4}{*}{ Urea } & 100 & 10.94 & 10.75 & 11.56 & 10.81 & 10.63 & 11.38 & 11.01 & 10.94 & 10.94 & 11.85 & 10.94 & 11.25 & 11.56 & 11.25 \\
\hline & 120 & 11.19 & 11.50 & 11.88 & 11.06 & 11.25 & 11.88 & 11.46 & 11.25 & 11.69 & 12.14 & 11.25 & 11.88 & 12.19 & 11.73 \\
\hline & 140 & 11.88 & 11.88 & 12.25 & 11.56 & 11.56 & 12.06 & 11.87 & 12.00 & 11.88 & 12.27 & 12.00 & 11.88 & 12.19 & 12.04 \\
\hline & mean & 11.34 & 11.38 & 11.90 & 11.14 & 11.15 & 11.77 & 11.45 & 11.40 & 11.50 & 12.09 & 11.40 & 11.67 & 11.98 & 11.67 \\
\hline \multirow{4}{*}{\begin{tabular}{|l} 
General \\
means o \\
N .rate \\
General m
\end{tabular}} & 100 & 11.07 & 11.13 & 11.75 & 10.88 & 11.10 & 11.63 & 11.26 & 11.10 & 11.41 & 11.86 & 11.00 & 11.57 & 11.75 & 11.45 \\
\hline & 120 & 11.47 & 11.69 & 12.01 & 11.31 & 11.47 & 11.88 & 11.64 & 11.50 & 11.79 & 12.15 & 11.41 & 11.88 & 12.10 & 11.81 \\
\hline & 140 & 11.88 & 12.04 & 12.22 & 11.56 & 11.72 & 12.03 & 11.91 & 12.00 & 11.94 & 12.26 & 11.94 & 12.04 & 12.10 & 12.04 \\
\hline & ean & 11.48 & 11.62 & 12.00 & 11.25 & 11.43 & 11.85 & & 11.54 & 11.71 & 12.09 & 11.45 & 11.54 & 11.98 & \\
\hline
\end{tabular}

(S)Soil application method

(F)Foliar application method

L.S.D at 0.05 for:

Sources
N. Rate

N. Rate
Micro element

Interaction

Interaction

Interaction

Interaction

(S)

(N)

(M)

SM

N M

SNM

$*$
0.10
0.15
0.14
0.21
0.25
N.S

